\title{
Pharmacological evaluation of a phytotherapeutic product - CPV (dry extract of Crataegus oxyacantha L., Passiflora incarnata L. and Valeriana officinalis $\mathbf{L}$.) in laboratory animals
}

\author{
Ricardo Tabach, Rita Mattei*, Elisaldo Luiz de Araujo Carlini
}

Universidade Federal de São Paulo, Departamento de Psicobiologia, Rua Botucatu, $8621^{\circ}$ andar, 04023-062

São Paulo-SP, Brazil

\begin{abstract}
RESUMO: "Avaliação farmacológica do produto fitoterápico - CPV (extrato seco de Crataegus oxyacantha L., Passiflora incarnata L. e Valeriana officinalis L.) em animais de laboratório". O presente estudo teve por objetivo avaliar em modelos animais, os possíveis efeitos do produto fitoterápico CPV (extrato seco de Crataegus oxyacantha, Passiflora incarnata e Valeriana officinalis) quanto à sua ação ansiolítica avaliada no modelo do labirinto em cruz elevado (LCE). Outros efeitos como neuroléptico (bloqueio da estereotipia por apomorfina), analgésico (testes: placa quente; retirada da cauda e contorções abdominais), bem como sobre a memória (esquiva passiva) também foram considerados. O extrato CPV (430 e $860 \mathrm{mg} / \mathrm{kg}$ ) apresentou um efeito ansiolítico (aumento do número de entradas nos braços abertos do LCE) em ratos e uma tendência de efeito amnésico para ambas as doses (430 e $860 \mathrm{mg} / \mathrm{kg})$, embora menos intenso quando comparado com o diazepam $(1,5 \mathrm{mg} / \mathrm{kg})$. O extrato não apresentou efeitos neuroléptico ou analgésico.
\end{abstract}

Unitermos: Passiflora incarnata, Crataegus oxyacantha, Valeriana officinalis, Passifloraceae, Rosaceae, Valerianaceae, atividade ansiolítica, SNC.

\begin{abstract}
The aim of the present study was to evaluate the central effects of the phytotherapeutic product-CPV (dry extract of Crataegus oxyacantha, Passiflora incarnata and Valeriana officinalis) in animals models. In order to investigate the psychopharmacological profile of CPV extract, an evaluation toward anxiolytic effect of this extract on the elevated plus-maze (EPM) was carried out. Other effects such as neuroleptic (blockade of the stereotyped behavior induced by apomorphine), analgesic (hot plate; acetic acid writhing and tail-flick tests) and on the memory (passive avoidance test) were also analyzed. CPV extract (430 and $860 \mathrm{mg} /$ $\mathrm{kg}$ ) presented an anxiolytic effect on rats (increased the number of entries into the open arms in the EPM) and, furthermore, a tendency of slight amnesic effect for the doses (430 and 860 $\mathrm{mg} / \mathrm{kg})$, but less intense when compared to diazepam $(1.5 \mathrm{mg} / \mathrm{kg})$. The extract did not show neuroleptic or analgesic effects.
\end{abstract}

Keywords: Passiflora incarnata, Crataegus oxyacantha, Valeriana officinalis, Passifloraceae, Rosaceae, Valerianaceae, anxiolytic effects, CNS.

\section{INTRODUCTION}

The association of various plants in a single medication is a relatively common practice in several countries. As examples, in France, Euphytose ${ }^{\circledR}$, an association of Passiflora incarnata, Valeriana officinalis, Crataegus oxyacantha, and three other plants, has been used for its anxiolytic properties (Valli et al., 1991). In Chinese therapeutics, the practice of associating various plants with a view to producing one specific therapeutic effect is widely known (Yuan and Lin, 2000). Authors suggest that these associations may result, indeed, in a better therapeutic effect when compared with each plant or even when compared to one active principle (Gilbert and Alves, 2003). The pharmacological effects attributed separately to each plant of a phytotherapeutic product - CPV (dry extract of Crataegus oxyacantha L., Passiflora incarnata L., and Valeriana officinalis L.) are well described in the literature. For instance, $P$. incarnata exerts anxiolytic, sedative and anticonvulsant actions (Speroni et al., 1996; Dhawan et al., 2001; Quintans-Júnior et al., 2008), C. oxyacantha possesses cardiotonic, antiatherogenic, and antioxidant effects, which would enhance its action on atherosclerosis (Shanthi et al., 1996) and $V$. officinalis was utilized traditionally as a sedative for light insomnia, in addition to being indicated for its anxiolytic properties 
when administered in smaller doses (Morazzoni \& Bombardelli, 1995; Cropley et al., 2002; Sousa et al., 2008). Its pharmacological effects are attributed to the presence of valepotriates and sesquiterpenes that would act on the GABA system (Yuan et al., 2004). This may account for its pharmacological effects on anxiety and depression (Santos et al., 1994). However, studies should be developed with a view to demonstrating that an association of plants will not produce any posterior toxic effects, possibly inexistent in individual components and, in addition, that the association will not annul the effects for which individual plants are utilized, nor give rise to unexpected effects. In a previous study with animals, carried out in our laboratory, it was verified that CPV extract did not produce toxicity worthy of note, even when administered in high doses and for a long period of time (Tabach et al., 2008). In the present study the possible central effects of the CPV extract were investigated with a view to establishing the psychopharmacological profile mainly in that which concerns a possible anxiolytic effect. We endeavored to verify, concomitantly, whether the extract might produce any other effect neuroleptic, analgesic, or exerts any effect on memory.

\section{MATERIAL AND METHODS}

\section{Animals}

Male albino Swiss mice, ( 3 to 4 months of age), weighing $30-40 \mathrm{~g}$ and male Wistar rats (3 months of age) weighing $300-400 \mathrm{~g}$ were obtained from the Department of Psychobiology, UNIFESP. Animals were maintained at constant room temperature (23 \pm $1{ }^{\circ} \mathrm{C}$ ) with a $12 \mathrm{~L}: 12 \mathrm{D}$ light schedule (lights on $6: 00$ a.m. to 6:00 p.m.) and free access to food and water. All the experiments were carried out in accordance to the norms of the Ethics Committee for Research of the Universidade Federal de São Paulo (CEP n: 1400/01). The animals used in this study were maintained in accordance with the guidelines of the Committee on Care and Use of Laboratory Animal Resources, National Research Council, USA.

\section{Botanical material}

The CPV extract consists in material obtained from: C. oxyacantha (Rosaceae), known in Brazil as "pilriteiro", a hawthorn a shrub native to Europe (Rigelsky and Sweet, 2002; Brandão et al., 2006); $P$. incarnata (Passifloraceae), known as maracujá, passion fruit, a creeper native to Tropical America (Soulimani et al., 1997; Marliére et al., 2008) and $V$. officinalis (Valerianaceae) a perennial plant, native to Europe and Western Asia (Morazzoni et al., 1995). The dry extracts of $C$. oxyacantha (batch $\mathrm{n}^{\circ} 04804 / \mathrm{M} 1$ ), $P$. incarnata (batch $\mathrm{n}^{\circ}$ 04675/M1) and $V$. officinalis (batch $\mathrm{n}^{\circ}$ 26961/ M2) were purchased by Biolab Sanus Farmacêutica Ltda. from Indena ${ }^{\circledR}$, having been identified through high efficiency liquid chromatography and, subsequently, assessed as to their physicochemical characteristics, residual contamination by organic solvents, and microbiological contamination following standards of reference, in accordance to the official reports supplied by Indena ${ }^{\circledR}$ (analysis certificates numbers 11580 C. oxyacantha, 11636 P. incarnata and $62706 \mathrm{~V}$. officinalis). These extracts were mixed in the following proportion: C. oxyacantha: $0.8 \mathrm{~kg}(26.7 \%)$, P. incarnata: $1.0 \mathrm{~kg}(33.3 \%)$ and $V$. officinalis: 1.2 $\mathrm{kg}(40 \%)$. This proportion was chosen based on the composition of a most used marketed product in Brazil that possesses the same amounts of the three extracts.

\section{Drugs}

Apomorphine hydrochloride; scopolamine bromide, morphine sulfate and pentylenetetrazol (Sigma Chemical Co St Louis, USA); diazepam (Roche do Brazil).

\section{Extract administration}

The CPV extract, diluted in water as needed, was administered either through oral or ip (intraperitoneal) routes in constant volume of $0.1 \mathrm{~mL} / 10 \mathrm{~g}$ of weight in mice and $0.1 \mathrm{~mL} / 100 \mathrm{~g}$ of weight in rats. Different concentrations of the extracts were used in order to obtain the desired dosage $(\mathrm{mg} / \mathrm{kg})$ for the animals; in all cases, a very fine stable suspension was obtained. The doses employed in the rats were based on the human daily dosage of the marketed phytomedicine available in Brazil (a pill of $300 \mathrm{mg}$ corresponding to $4.3 \mathrm{mg} / \mathrm{kg}$ for an adult of $70 \mathrm{~kg}$; doses 100 and 200 times larger were also employed).

\section{Evaluation of the anxiolytic effect}

\section{Elevated plus- maze (EPM)}

The maze consists of two open arms and two closed arms by $30 \mathrm{~cm}$ high walls. Each arm measures 50 $\mathrm{cm}$ of length by $10 \mathrm{~cm}$ of width and contains a central square of $10 \times 10 \mathrm{~cm}$. The maze was $60 \mathrm{~cm}$ above the floor. Four groups of 10 animals each, being them control (water, oral), diazepam (1.5 mg/kg, ip), and CPV extract (430 and $860 \mathrm{mg} / \mathrm{kg}$, oral), were placed in the center of the maze and recorded the number of times they entered the open and closed arms, as well as how long they stayed there within $5 \mathrm{~min}$. In order to evaluate their level of emotionality, we considered their number of entries in the open arms and the time they remained there: the higher the number, the lower their level of emotionality (Pellow et al., 1985; Fenner, et al., 2008). 


\section{Antipentylenetetrazol effect}

Three groups of 10 mice each were given water (control) or CPV extract (430 and $860 \mathrm{mg} /$ $\mathrm{kg}$ ), by mouth. After $60 \mathrm{~min}$, the animals were given pentylenetetrazol $(100 \mathrm{mg} / \mathrm{kg}$, sc), and the latency time for the onset of clonic or tonic convulsions was observed (Mattei et al., 1995).

\section{Other pharmacological effects}

\section{Effect on memory and learning (Passive avoidance test)}

Three groups of 10 mice each, being them control (water, oral) and CPV extract (430 and $860 \mathrm{mg} / \mathrm{kg}$, oral) were administered. After $30 \mathrm{~min}$ the animals were given a dose of scopolamine $(0.5 \mathrm{mg} / \mathrm{kg}$, ip) 30 , and were subjected to the test after $30 \mathrm{~min}$. The passive avoidance task was measured in an apparatus consisting of one light and one dark compartment. After treatment, each animal was placed in the light compartment and the time was measured of how long it took to move into the dark compartment (acquisition latency). A shock of $1.0 \mathrm{~mA} / 2 \mathrm{~s}$ was applied as soon as the animal stepped into the dark compartment. Immediately after that the animals returned to its homecage and $24 \mathrm{~h}$ later, replaced into the light compartment in order to measure the time it took to move from the light side into the dark one (retention latency). Animals that did not enter after 180s were removed from the apparatus, and $180 \mathrm{~s}$ were noted as time of retention (Galvão et al., 2002).

Table 1. Time of latency for clonic and tonic convulsions induced by $100 \mathrm{mg} / \mathrm{kg}$ of pentylenetetrazol in mice.

\begin{tabular}{lccc}
\hline Treatment & $\begin{array}{c}\text { Dose } \\
(\mathrm{mg} / \mathrm{kg})\end{array}$ & $\begin{array}{c}\text { Clonic convulsions (latency } \\
\text { in min) }\end{array}$ & $\begin{array}{c}\text { Tonic convulsions (latency in min) } \\
\text { Control }\end{array}-^{---}$ \\
CPV Extract & 430 & $4.9 \pm 1.7$ & $10.5 \pm 7.2$ \\
CPV Extract & 860 & $3.3 \pm 3.0$ & $5.6 \pm 4.1^{*}$ \\
\hline
\end{tabular}

$(*) \mathrm{p}<0.05$ differs in relation to control. (ANOVA / Duncan’s test).

Table 2. Effects of CPV extract on a stereotype behavior induced by $5 \mathrm{mg} / \mathrm{kg}$ (ip) of apomorphine over the course of time.

\begin{tabular}{lcccccc}
\hline & \multicolumn{5}{c}{ Treatment } & \multicolumn{5}{c}{$\begin{array}{c}\text { Degrees of stereotype behavior over the course of time } \\
\text { (median } \pm \text { interquartile) }\end{array}$} \\
\hline Groups & Dose (mg/kg) & $5 \mathrm{~min}$ & $15 \mathrm{~min}$ & $30 \mathrm{~min}$ & $45 \mathrm{~min}$ & $60 \mathrm{~min}$ \\
Control & --- & $3.0 \pm 0$ & $5.0 \pm 1$ & $7.0 \pm 3$ & $6.0 \pm 2$ & $4.0 \pm 2$ \\
CPV Extract & 430 & $4.0 \pm 0.5$ & $5.5 \pm 1$ & $7.0 \pm 0.5$ & $7.0 \pm 0$ & $4.0 \pm 4$ \\
CPV Extract & 860 & $3.5 \pm 2$ & $6.5 \pm 1.5$ & $7.0 \pm 1.5$ & $6.0 \pm 2$ & $5.5 \pm 3.5$ \\
\hline
\end{tabular}

NS ( $>0.05$, ANOVA).

Table 3. Measurement of analgesic effect of CPV extract in mice, assessed by: a) hot plate test; b) induction of writhing by acetic acid; c) tail-flick test.

\begin{tabular}{|c|c|c|c|c|c|c|}
\hline \multicolumn{2}{|c|}{ Treatments } & \multicolumn{2}{|c|}{$\begin{array}{l}\text { a) Time (s) of } \\
\text { permanence on hot } \\
\text { plate }(x \pm d p)\end{array}$} & \multirow{2}{*}{$\begin{array}{l}\begin{array}{l}\text { b) Number of } \\
\text { writhing } \\
(\mathrm{x} \pm \mathrm{dp})\end{array} \\
\text { Amount }\end{array}$} & \multicolumn{2}{|c|}{$\begin{array}{l}\text { c) Time (s) for removal of tail (tail- } \\
\text { flick) }(x \pm d p)\end{array}$} \\
\hline Groups & $\begin{array}{c}\text { Dose (mg/ } \\
\text { kg) }\end{array}$ & $30 \mathrm{~min}$ & $60 \mathrm{~min}$ & & $30 \min$ & $60 \mathrm{~min}$ \\
\hline Control & --- & $8.2 \pm 3.1$ & $9.8 \pm 4.3$ & $7.1 \pm 3.1$ & $2.8 \pm 1.7$ & $2.7 \pm 1.0$ \\
\hline Morphine & 10 & $22.4 \pm 7.6^{*}$ & $18.9 \pm 7.4^{*}$ & $1.7 \pm 2.2 *$ & $4.9 \pm 5.3$ & $4.5 \pm 2.9^{*}$ \\
\hline CPV Extract & 1.250 & $15.0 \pm 9.3$ & $15.1 \pm 7.1$ & $6.1 \pm 3.5$ & $1.7 \pm 1.0$ & $2.9 \pm 0.8$ \\
\hline CPV Extract & 2.500 & $11.8 \pm 37$ & $9.2 \pm 3.4$ & $6.2 \pm 2.6$ & $2.6 \pm 1.2$ & $4.1 \pm 2.4$ \\
\hline
\end{tabular}

$(*) \mathrm{p}<0.05$ compared with control. (ANOVA/Duncan’s test). 

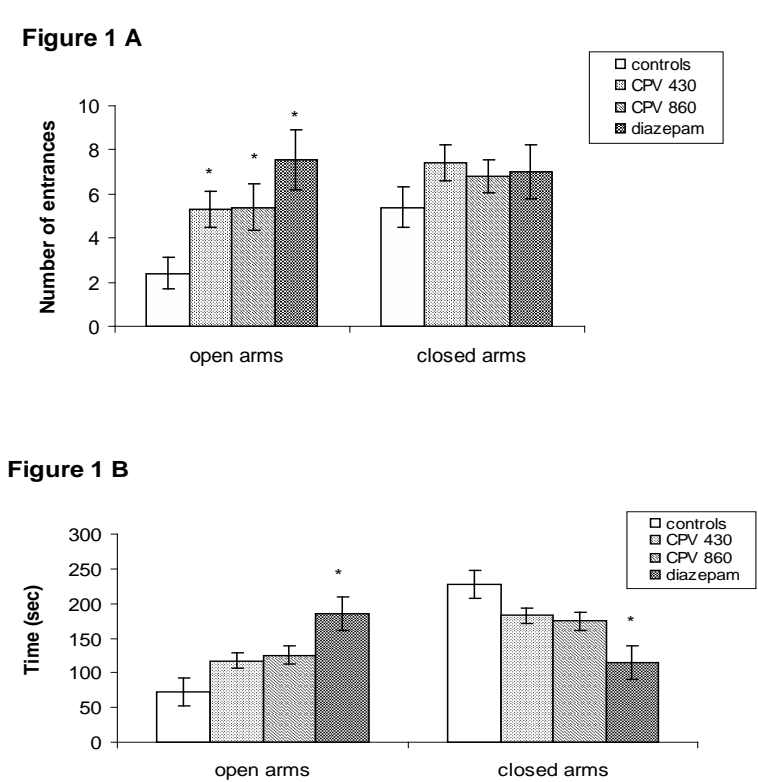

Figure 1. Number of entrances (A) and time (s) of permanence (B) on the open and closed arms of rats orally treated with water (control), CPV extract (430 and $860 \mathrm{mg} / \mathrm{kg}$ ) and diazepam $(1.5 \mathrm{mg} / \mathrm{kg})$. The values are expressed by means \pm standard error (SEM). (*) Difference between control and other groups. $\mathrm{p}<0.05$ (ANOVA/Duncan's test).

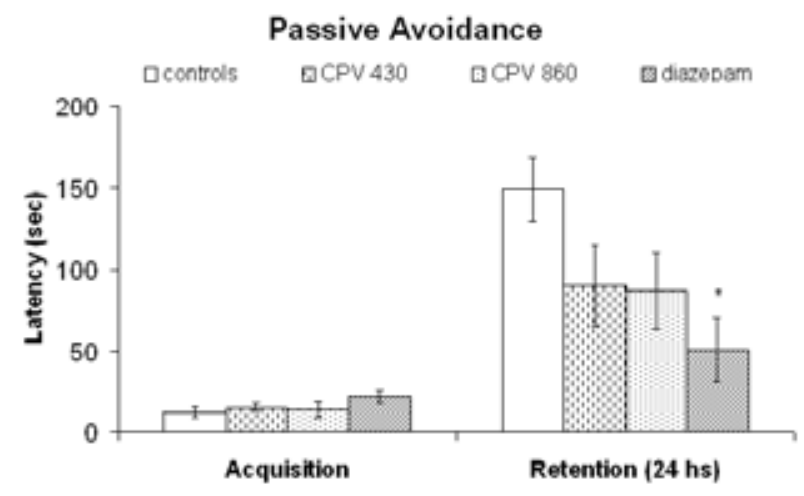

Figure 2. Latency of acquisition and retention at the passive avoidance test of mice orally treated with: water (control), CPV extract (430 and $860 \mathrm{mg} / \mathrm{kg}$ ) and diazepam $(1.5 \mathrm{mg} / \mathrm{kg}$ ). The values are expressed by means \pm standard error (SEM). (*) Difference between control and other groups $\mathrm{p}<0.05$ (Kruskall-Wallis/Mann-Whitney Test).

\section{Neuroleptic effect}

\section{Blockade of the stereotyped behavior induced by apomorphine}

Three groups of 10 rats each, being them control (water, oral) and CPV extract (430 and $860 \mathrm{mg} / \mathrm{kg}$, oral), were placed individually in wire cages and, after $30 \mathrm{~min}$, were given apomorphine ( $5 \mathrm{mg} / \mathrm{kg}$, ip). They were observed for $60 \mathrm{~min}$ and the degrees of stereotyped behavior recorded (Galvão et al., 2005).

\section{Analgesic effect}

\section{Hot plate test}

Four groups of 10 mice each received water (control, oral) and CPV extract (430 and $860 \mathrm{mg} / \mathrm{kg}$, oral). A positive control was given morphine $(10 \mathrm{mg} /$ $\mathrm{kg})$. The animals were subjected to the test before (basal) and after 15, 30, 60, and 120 minutes from administering, measuring reaction time to thermal stimulus $\left(55^{\circ} \mathrm{C}\right)$ characterized by the animal's reaction in "dancing" on the plate and/or licking its paws. A maximum of $30 \mathrm{~s}$. was established to prevent damage to the animal's paws (Mendes et al., 2002).

\section{Acetic acid writhing test}

Four groups of 10 mice each were given water (control, oral), morphine (10 mg/kg, ip), and CPV extract (430 and $860 \mathrm{mg} / \mathrm{kg}$, oral). After 30 minutes, they were injected with acetic acid ( $0.6 \%$ ip). The cumulative number of writhing responses (abdominal constriction) was recorded for 30 min (Perazzo et al., 2008).

\section{Tail-flick test}

Four groups of 10 rats each were given water (control, oral), morphine (10 mg/kg ip), and CPV extract (430 and $860 \mathrm{mg} / \mathrm{kg}$, oral). The animals were subjected to the test before (basal) and after 15, 30, 60 , and 120 minutes from administering, measuring the latency for removing the tail positioned on a bulb projecting heat previously adjusted to produce a basal reaction time between 4 and $6 \mathrm{~s}$. The reflex for removing the tail was automatically measured through a photodetector up to a maximum of $15 \mathrm{~s}$. (Mendes et al., 2002; Perazzo et al., 2008).

\section{Statistical analysis}

The data obtained from the passive avoidance were analyzed by the Kruskal-Wallis Test followed by the Mann-Whitney U Test. The results obtained with the other tests were subjected to an Analysis of Variance (ANOVA) followed by the Duncan's Test. Differences were considered statistically significant when $\mathrm{p} \leq 0.05$.

\section{RESULTS}

\section{Evaluation of the anxiolytic effect}


CPV extract, at the doses of 430 and $860 \mathrm{mg} /$ $\mathrm{kg}$, increased the number of entrances of the animals into the open arms of the EPM and these results were statistically different when compared to the control group (Figure 1A). There was a tendency $(p=0.057)$ for the experimental animals (CPV $860 \mathrm{mg} / \mathrm{kg}$ ) to remain longer in the open arms when compared to the control group (Figure 1B). These parameters are indicative of the degree of emotionality of the animals, suggesting an anxiolytic effect from CPV extract (Pellow et al., 1985). Diazepam, at the dose of $1.5 \mathrm{mg} / \mathrm{kg}$, increased both the number of entrances and the time spent on the open arms in a statistically significant way (Figure 1A, 1B).

The time of latency for clonic and tonic convulsions induced by $100 \mathrm{mg} / \mathrm{kg}$ of pentylenetetrazol in experimental group was similar to control group, except for the latency to tonic convulsions with 460 $\mathrm{mg} / \mathrm{kg}$ of CPV (Table 1).

\section{Other pharmacological effects}

The results obtained in the passive avoidance test showed that diazepam induced a statistically significant worsening in the memory of the animals (Figure 2), in such a way that, when they were placed in the apparatus in which they had been given shocks the previous day, they moved, quickly, to the side where they had received the shock 24 hours previously. The doses of 430 and $860 \mathrm{mg} / \mathrm{kg}$ of CPV also presented results in the same direction, which, however, did not attain statistical significance; in fact, both the comparison of control versus CPV $430 \mathrm{mg} / \mathrm{kg}$ $(p \leq 0.13)$ and the comparison control versus CPV 860 $\mathrm{mg} / \mathrm{kg}(\mathrm{p} \leq 0.57)$ seem to indicate an effect so similar to diazepam that there was no statistically significant difference between the 3 treatments.

CPV extract was not successful at blocking the stereotyped behavior produced by apomorphine (Table 2) and did not per se induce catalepsy, nor block this behavior when induced by haloperidol (data not shown were observed).

CPV extract was not effective at blocking the nociceptive effect (Table 3) induced by heat (hot plate and tail-flick tests) or by peritoneal irritation (injection of acetic acid intraperitoneally). Morphine, positive control, showed a clear analgesic effect in these 3 tests.

\section{DISCUSSION}

Several authors have supported the point of view that the use of plant extracts, whether singly or associated, within a single medication, may have better therapeutic effects than the individual use of the isolated active principle(s); these authors postulate that this synergism is the result of pharmacokinetic and/or pharmacodynamic factors (Williamson, 2001; Gilbert and Alves, 2003). In this respect, the properties of two of the plants that make up the phytotherapeutic product under study should be emphasized: valepotriates present in $V$. officinalis reverted the anxiety of the rats at the EPM during diazepam abstinence (Andreatini et al., 2002) and the anxiolytic effects of this plant on human beings were also observed (Poyares et al., 2002). P. incarnata has anxiolytic and sedative properties attributed to the presence of flavonoids and alkaloids exerting action on benzodiazepinic receptors (Speroni et al., 1996; Bourin, et al., 1997). The three plants that make up CPV extract are also part of two commercial products that are utilized therapeutically as anxiolytics (Hiller and Zetler, 1996). However, the CPV extract did not protect mice from tonic or clonic convulsions induced by pentylenetetrazol. It is of interest to note that both $V$. officinalis and $P$. edulis do not protect mice from convulsion by pentylenetetrazol (Valle and Leite, 1983; Hiller and Zetler, 1996).

In synthesis, the present study shows that CPV extract was successful in reducing the anxiety of the animals when assessed in the EPM. This anxiolytic effect is also present in isolated extracts from at least two of the plants, Passiflora (Bourin et al., 1997) and Valeriana (Andreatini et al., 2002). Similarly to diazepam and other benzodiazepines (Schweizer and Rickels, 1997), CPV extract also proved to exert an amnesic effect, although less intense than produced by diazepam, which might be an advantage from the therapeutic point of view. Therefore, presents a pharmacological profile similar to that of diazepam, and does not present a neuroleptic, or analgesic effect.

\section{ACKNOWLEDGMENTS}

This study was partially funded by AFIP (Associação Fundo de Incentivo à Psicofarmacologia) and Laboratórios Biolab Sanus Farmacêutica Ltda.

\section{REFERENCES}

Andreatini R, Sartori VA, Seabra MLV, Leite JR 2002. Effects of valepotriates (valerian extract) in generalized anxiety disorder: a randomized placebo-controlled pilot study. Phytother Res 6: 650-654.

Bourin M, Bougerol T, Guitton B, Broutin E 1997.A combination of plant extracts in the treatment of outpatients with adjustment disorder with anxious mood: controlled study versus placebo. Fund Clin Pharmacol 11: 127-132.

Brandão MGL, Cosenza GP, Moreira RA, Monte-Mor RLM 2006. Medicinal plants and other botanical products from the Brazilian Official Pharmacopoeia. Rev Bras Farmacogn 16: 408-420.

Cropley M, Cave Z, Ellis J, Middleton W 2002. Effect of Kava and Valerian on human physiological and psychological responses to mental stress assessed under laboratory conditions. Phytother Res 16: 2327. 
Dhawan K, Kumar S, Sharma A 2001. Comparative biological activity study on Passiflora incarnata and P. edulis. Fitoterapia 72: 698-702.

Fenner R, Zimmer AR, Neves G, Kliemann M, Gosmann G, Rates SMK 2008. Hypnotic effect of ecdysterone isolated from Pfaffia glomerata (Spreng.) Pedersen. Rev Bras Farmacogn 18: 170-176.

Galvão SMP, Marques LC, Oliveira MGM, Carlini EA 2002. Heteropterys aphrodisiaca (extract BST0298): a Brazilian plant that improves memory in aged rats. $J$ Ethnopharmacol 79: 305-311.

Galvão SMP, Mendes FR, Oliveira MGM, Mattei R, Carlini EA 2005. Possíveis efeitos adaptógenos da Heteropterys aphrodisiaca O Mach. - Extrato BST0298: uma planta da área do Pantanal Brasileiro. Arq Bras Fitomed Cient 2: 41-55.

Gilbert B, Alves LF 2003. Synergy in plant medicines. Curr Med Chem 10: 13-20.

Hiller KO, Zetler G 1996. Neuropharmacological studies on ethanol extracts of Valeriana officinalis L.: behavioural and anticonvulsant properties. Phytother Res 10: 145-151.

Mattei R, Leite JR, Tufik S 1995. A study of the pharmacological actions of Dioclea grandiflora Mart ex Bent. São Paulo Med J 113: 687-692

Mendes FR, Mattei R, Carlini EA 2002. Activity of Hypericum brasiliense and Hypericum cordatum on the central nervous system in rodents. Fitoterapia 73: 462-471.

Marliére LDP, Ribeiro AQ, Brandão MGL, Klein CH, Acurcio FA 2008. Utilização de fitoterápicos por idosos: resultados de um inquérito domiciliar em Belo Horizonte (MG), Brasil. Rev Bras Farmacogn 18 (Supl.): 754-760.

Morazzoni P, Bombardelli E 1995.Valeriana officinalis: traditional use and recent evaluation of activity. Fitoterapia 66: 99-112.

Pellow S, Chopin P, File SE, Briley M 1985. Validation of open closed arm entries in an elevated plus maze as a measure of anxiety in the rat. J Neurosci Meth 14: 149-167.

Perazzo FF, Lima LM, Padilha MM, Rocha LN, Pergentino JCS, Carvalho JCT 2008. Anti-inflammatory and analgesic activities of Hypericum brasiliense (Willd) standardized extract. Rev Bras Farmacogn 18: 320325.

Poyares DR, Guilleminault C, Ohayon MM, Tufik $\mathrm{S}$ 2002. Can valerian improve the sleep of insomnia after benzodiazepine withdrawal? Prog Neuropsychopharmacol Biol Psychiatry 26: 539545.

Quintans-Júnior LJ, Almeida JRGS, Lima JT, Nunes XP, Siqueira JS, Oliveira LEG, Almeida RN, AthaydeFilho PF, Barbosa-Filho JM 2008. Plants with anticonvulsant properties - a review. Rev Bras Farmacogn 18 (Supl.): 798-819.

Rigelsky JM, Sweet BV 2002. Hawthorm: pharmacology and therapeutic uses. Am J Health Syst Pharm 59: 417422.

Santos MS, Ferreira F, Cunha AP, Carvalho AP, Ribeiro CF, Macedo T 1994. Synaptosomal GABA release as influenced by valerian root extract involvement of the GABA carrier. Arch Int Pharmacodyn Ther 327: 220-231.
Schweizer E, Rickels K 1997. Strategies for treatment of generalized anxiety in the primary care setting. $J$ Clin Psychiatry 58: 27-33.

Shanthi R, Parasakthy K, Deepalakshmi PD, Niranjali DS 1996. Protective effect of tincture of Crataegus on oxidative stress in experimental atherosclerosis in rats. J Clin Biochem Nutr 20: 211-223.

Soulimani R, Younos C, Jarmouni S, Bousta D, Misslin R, Mortier F 1997. Behavioral effects of Passiflora incarnata L. and its indole alkaloid and flavonoid derivatives and maltol in the mouse. $J$ Ethnopharmacol 57: 11-20.

Sousa FCF, Melo CTV, Citó MCO, Félix FHC, Vasconcelos SMM, Fonteles MMF, Barbosa-Filho JM, Viana GSB 2008. Plantas medicinais e seus constituintes bioativos: Uma revisão da bioatividade e potenciais benefícios nos distúrbios da ansiedade em modelos animais. Rev Bras Farmacogn 18: 642-654.

Speroni E, Billi R, Mercati V, Boncompagni E, Toja E 1996. Sedative effects of crude extract of Passiflora incarnata after oral administration. Phytother Res 10: 92-94.

Tabach R, Rodrigues E, Carlini EA 2008. Preclinical toxicological assessment of a phytotherapeutic product - CPV (based on dry extracts of Crataegus oxyacantha L., Passiflora incarnata L., and Valeriana officinalis L.). Phytother Res 23: 33-40.

Valle NB, Leite JR 1983. Efeitos psicofarmacológicos de preparações de Passiflora edulis (maracujá). Cienc Cult 35: 11-24.

Valli M, Paubert-Braquet M, Picot S, Fabre R, Lefrançois G, Rod D 1991. Euphytose ${ }^{\circledR}$ an association of plant extracts with anxiolytic activity: investigation of its mechanisms of action by an in vitro binding study. Phytother Res 5: 241-244.

Williamson EM 2001. Synergy and other interactions in phytomedicines. Phytomedicine 8: 401-409.

Yuan R, Lin Y 2000. Traditional Chinese medicine: an approach to scientific proof and clinical validation. Pharmacol Ther 86: 191-198.

Yuan CS, Mehendale S, Xiao Y, Aung HH, Xie JT, AngLee MK 2004. The gamma-aminobutyric acidergic effects of valerian and valerenic acid on rat brainstem neuronal activity. Anesth Analg 98: 353-358. 